\title{
Tuberous sclerosis: possible modification of phenotypic expression by an unlinked dominant gene ${ }^{1}$
}

\author{
ALAN R. RUSHTON AND BENNETT A. SHAYWITZ \\ From the Departments of Pediatrics and Neurology, Yale University School of Medicine, \\ New Haven, USA
}

SUMMARY A unique pedigree is presented which shows tuberous sclerosis in three generations of $\vec{a}$ family, in which two heterozygotes for the mutant gene were found to be clinically asymptomatio. A genetic model is proposed to explain these findings based upon the segregation of a second unlinke्d autosomal dominant gene modifying the expression of the gene for tuberous sclerosis.

Tuberous sclerosis is an autosomal dominant disorder characterised by mental retardation, epilepsy, and adenoma sebaceum. Associated lesions include retinal phakomata, shagreen patches, white naevi, subungual fibromata, and benign visceral tumours. Affected persons may exhibit milder forms of the disease, such as skin or eye lesions alone without retardation or epilepsy (Donegani et al., 1972). The disease may rarely be diagnosed at necropsy in a patient who appeared to be clinically unaffected (Lagos and Gomez, 1967; Tsukada and Pickren, 1967).

The inheritance of tuberous sclerosis has been studied in several large series of patients. About $80 \%$ of cases appear to be sporadic mutations, arising in families with no other affected relatives. These cases are identical to those which are familial. Extensive pedigree analysis has shown an autosomal dominant inheritance pattern with variable expressivity in affected family members. No instances of a 'skip' generation have been noted, that is, one in which a heterozygote did not have any symptoms of the disease (Borberg, 1951; Dickerson, 1951; Marshall et al., 1959; Nevin and Pearce, 1968; Zaremba, 1968; Bundey and Evans, 1969; Singer, 1971; François, 1975; Ponsot and Lyon, 1977).

The purpose of this paper is to report the pedigree of a patient with tuberous sclerosis; this appears to show heterozygotes with the mutant gene, but without clinical symptoms. A genetic model is proposed to explain these findings based on a second unlinked autosomal dominant gene modifying the expression of the tuberous sclerosis gene.

1 Supported by grants NIH-Rol2384 and RR00125.
Received for publication 8 June 1978

\section{Case report}

The propositus (IV.5, Fig. 1) was a 5-year-old boy who presented at age 4 months with grand maj seizures, which were controlled with phenobarbitoffe and phenytoin. At 2 years, he was mentally retardga and had adenoma sebaceum, intracerebral calcifications, and a phakoma in the left eye. The diagnos of tuberous sclerosis was made. At age $4 \frac{1}{2}$ years, Me developed headaches, increasing lethargy, ad blurred vision. A CAT scan showed a vascular mass in the left cerebral hemisphere adjacent to the thigh ventricle which, at operation, was found to be a giant cell astrocytoma.

Complete physical examination (including skin examination by Wood's lamp) was performed on the patient's sister, aged 9 years (IV.4), mother (III.32), father (III.9), and maternal grandfather (II.12). signs or symptoms of tuberous sclerosis were foung.

A maternal great-uncle (II.11) had died at age $\$ 0$ after operation for bilateral brain tumours and seizures since childhood. Skin lesions were ngt described at necropsy, but he probably had tuberous sclerosis. A maternal uncle (III.36) had the diseasse with adenoma sebaceum, mental retardation, and seizures since childhood. Other family members have none of the signs of tuberous sclerosis.

\section{Discussion}

Tuberous sclerosis is an inherited disease chardeterised by variable phenotypic expressivity. Patients may have adenoma sebaceum alone or in combin tion with epilepsy, mental retardation, shagre 8 n patches, white naevi, retinal phakomata, or viscegal 


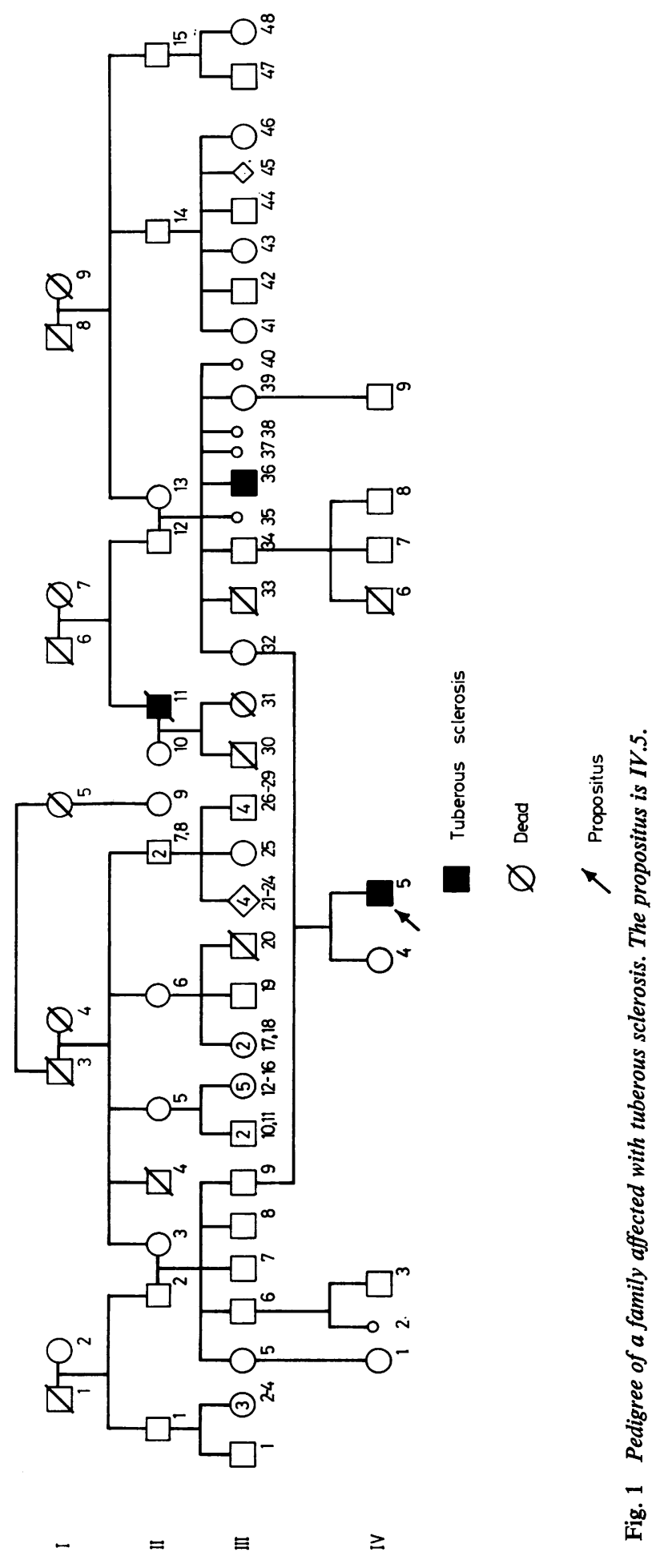


tumours (Lagos and Gomez, 1967). This variability has been attributed by different authors to the action of environmental factors and postulated modifier genes (Gunther and Penrose, 1935; Cuendet, 1961; Nevin and Pearce, 1968; Bundey and Evans, 1969; François, 1975).

Gunther and Penrose (1935) postulated that a gene A existed which modified the expression of the tuberous sclerosis gene E. In their model, the genotype EeAA was normal, EeAa was mildly affected, and Eeaa was severely affected. The theoretical frequencies of cases affected in these varying degrees corresponded fairly well to the number observed in a collected series of pedigrees, but in no cases were phenotypically normal heterozygotes of genotype EeAA documented.

Several pedigrees have been published in older reports which appear to show the inheritance of tuberous sclerosis from an unaffected heterozygote (Gunther and Penrose, 1935; Vaas, 1940). These findings may, however, be the result of incomplete examination (Cuendet, 1961). More recent large series have failed to document any such 'skip' generations (Borberg, 1951; Dickerson, 1951; Lagos and Gomez, 1967; Nevin and Pearce, 1968; Zaremba, 1968; Bundey and Evans, 1969; François, 1975; Ponsot and Lyon, 1977).

The pedigree in this report has shown two apparent heterozygotes for tuberous sclerosis who were clinically asymptomatic but who produced affected progeny. This has provided a unique opportunity to examine the segregation and expressivity of the

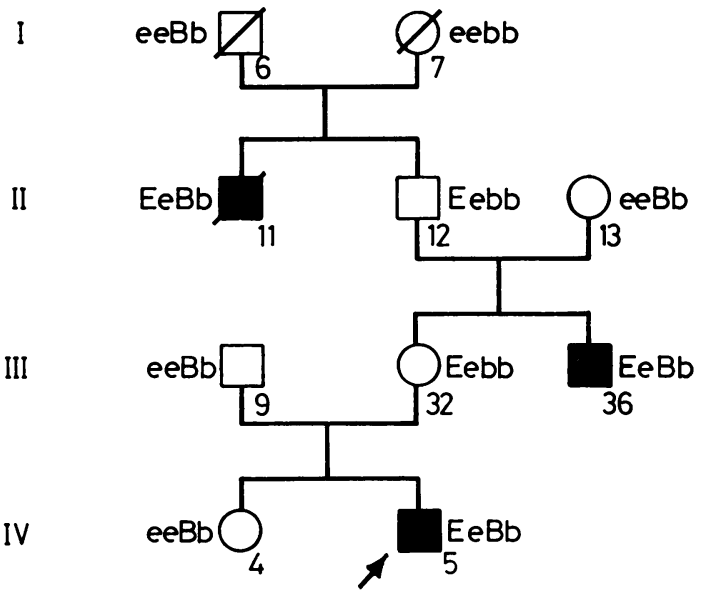

Fig. 2 Partial pedigree of the family affected with tuberous sclerosis. Presumptive genotype is assigned to each individual. E, tuberous sclerosis gene; $B$, dominant modifier gene. Other symbols are the same as Fig. 1. tuberous sclerosis gene in several generations of ope family. A genetic model to explain the findings in this family involves the modification of expressi@ of the dominant tuberous sclerosis gene $\mathrm{E}$ by anothe postulated unlinked dominant gene B. The presene of $B$ is required for the phenotypic expression of $f$. Fig. 2 presents the pedigree of this family wig presumptive genotypes assigned to each indivudaf. The maternal great-uncle (II.11) had tuberous sclerosis and genotype $\mathrm{EeBb}$. The maternal grandfather (II.12) is a heterozygote for the disease but $d \dot{d}$ clinically normal; his genotype, therefore, must Eebb. The mother of the index case (III.32) is also normal heterozygote Eebb, but her brother (III.36) has tuberous sclerosis and genotype EeBb. The propositus (IV.5) has the disease (gentoype EeBb) while his sister is normal (genotype Ee/eebb). The affected individuals in this family had severe symtoms, and it is possible that other genes exist whictt could modify the clinical spectrum of the disease. $\mathbb{D}$

The great majority of the cases of tuberous sclerosis appear to be the result of new mutations. Thus, most affected patients have clinically normal parents. The cases in this report indicate that normal parents cap in fact, be carriers of this genetic disease and would have a $50 \%$ probability of transmitting this dominam gene to each of their progeny. Detailed investigation of the pedigree of each family with an affected individual must, therefore, be completed for knowoledgeable genetic counselling and family planning.

\section{References}

Borberg, A. (1951). Clinical and genetic investigations in tuberous sclerosis and Recklinghausen's neurofibromatos $\overline{\text { R }}$. Acta Psychiatrica et Neurologica Scandinavica, 71, (Supptr: 11-239.

Bundey, S., and Evans, K. (1969). Tuberous sclerosis: ت7t genetic study. Journal of Neurology, Neurosurgery a Psychiatry, 32, 591-603.

Cuendet, J. F. (1961). Les phacomatoses. Bibliothę Paediatrica, 76, 253-271.

Dickerson, W. W. (1951). Familial occurrence of tubero sclerosis. Archives of Neurology and Psychiatry, 65, 683-703

Donegani, G., Grattarola, F. R., and Wildi, E. (19T28. Tuberous sclerosis. In Handbook of Clinical Neurolog $\overline{7}$; Vol. 14, pp. 340-389. Ed. by P. J. Vinker and G. W. Bruyd North-Holland, Amsterdam.

François, J. (1975). Les difficultés du conseil génétique daữ les phacomatoses. Journal de Génétique Humaine, $2 \mathcal{W}_{3}$ 17-24.

Gunther, M., and Penrose, L. S. (1935). The genetics of epiloia. Journal of Genetics, 31, 413-428.

Lagos, J. C., and Gomez, M. R. (1967). Tuberous scleros reappraisal of a clinical entity. Mayo Clinic Proceedings, 42, 26-49.

Marshall, D., Saul, G. B., and Sachs, E. (1959). Tubero sclerosis: a report of 16 cases in two family trees revealify genetic dominance. New England Journal of Medicine, 26\%, 1102-1105. 
Nevin, N. C., and Pearce, W. G. (1968). Diagnostic and genetical aspects of tuberous sclerosis. Journal of Medical Genetics, 5, 273-280.

Ponsot, G., and Lyon, G. (1977). La sclerose tubereuse de Bourneville. Archives Françaises de Pédiatrie, 34, 9-22.

Singer, K. (1971). Genetic aspects of tuberous sclerosis in a Chinese population. American Journal of Human Genetics, 23, 33-40.

Tsukada, Y., and Pickren, J. W. (1967). Carcinoma of breast and asymptomatic tuberous sclerosis. New York State Journal of Medicine, 67, 593-597.
Vaas, J. (1940). Klinik und Erbgang der tuberösen Sklerose. Archiv für Psychiatrie und Nervenkrankheiten, 111, 547-614.

Zaremba, J. (1968). Tuberous sclerosis: a clinical and genetic investigation. Journal of Mental Deficiency Research, 12, 63-80.

Requests for reprints to Dr Alan R. Rushton, Department of Pediatrics, Yale-New Haven Medical Center, New Haven, Connecticut 06510, USA. 